\title{
SCIENTIFIC REPORTS

\section{OPEN Amplicon sequencing analysis of arbuscular mycorrhizal fungal communities colonizing maize roots in different cover cropping and tillage systems}

\begin{abstract}
Masao Higo*, Yuya Tatewaki, Karen lida, Kana Yokota \& Katsunori Isobe
Our understanding regarding the influence of intensive agricultural practices, including cover cropping and tillage, on communities of arbuscular mycorrhizal fungi (AMF) is lacking. This would prove to be an obstacle in the improvement of current maize (Zea mays L.) production. Therefore, using amplicon sequencing, we aimed to clarify how AMF communities and their diversity in maize roots vary under different cover cropping systems and two types of tillage (rotary and no tillage). Two kinds of cover crops (hairy vetch and brown mustard) and fallow treatments were established with rotary or no tillage in rotation with maize crops. Tillage and no tillage yielded a set of relatively common AMF operational taxonomic units (OTUs) in the maize crops, representing $78.3 \%$ of the total OTUs. The percentage of maize crop OTUs that were specific to only tillage and no tillage were $9.6 \%$ and $12.0 \%$, respectively. We found that tillage system significantly altered the AMF communities in maize roots. However, the AMF communities of maize crops among cover cropping treatments did not vary considerably. Our findings indicate that compared with cover cropping, tillage may shape AMF communities in maize more strongly.
\end{abstract}

Growing cover crops and practicing conservation tillage are agricultural practices worldwide that have been recommended to promote soil fertility. In particular, Williams et al. ${ }^{1}$ reported that conservation tillage, including reduced or no tillage, modifies water-holding capacity and structure of soil in conservative agricultural systems. In general, conservation tillage can improve soil aggregation, increase the amount of soil organic carbon in the surface layer, and reduce erosion ${ }^{2,3}$. Moreover, conservation tillage enhances soil microbial diversity and the abundance of beneficial functional soil microorganisms ${ }^{3,4}$. The soil microbial communities stimulated by conservation tillage can play important roles in soil aggregation, soil carbon sequestration, and soil nutrition; improve water use efficiencies; and influence crop yields ${ }^{5,6}$.

The practice of cover cropping potentially reduces soil and wind erosion ${ }^{7}$, enhances soil organic matter ${ }^{8}$, inhibits weed establishment ${ }^{9}$, and increases the abundance and activity of arbuscular mycorrhizal fungi (AMF) ${ }^{10}$. Indeed, crops with AMF have a greater capacity to take up phosphorus $(\mathrm{P})$, zinc $(\mathrm{Zn})$, and water ${ }^{10}$ than crops without AMF. This greater capacity generally results in robust crop growth under conditions of limited nutrient availability or drought. AMF also contribute to increasing plant resistance against pathogens and help make crops generally healthier ${ }^{11-13}$. AMF also contribute to crop health indirectly because of their effects on soil processes in agricultural settings ${ }^{14,15}$. In particular, they can contribute to soil health, soil aggregate formation, and soil stability by increasing the soil's nutrient cycling and organic matter content ${ }^{16,17}$. However, certain agricultural practices have negative influences on AMF abundance and functions ${ }^{18,19}$. For example, conventional tillage systems, including chisel plowing, rotary tillage, and disc harrowing, can disrupt the AMF hyphal network ${ }^{20}$, inhibit AMF development and decrease AMF abundance in soil ${ }^{21}$. Fallowing during the winter also decreases the AMF abundance in soil and reduces the benefit of AMF on $\mathrm{crops}^{22,23}$. In contrast, no-tillage or reduced tillage systems can increase the abundance and hyphal network of AMF in soil ${ }^{20,24}$. Growing cover crops as pre-crops can increase 


\begin{tabular}{|l|l|l|l|l|l|}
\hline \multirow{2}{*}{ Tillage } & Cover crop type & Sowing time & $\begin{array}{l}\text { Termination and } \\
\text { incorporation }\end{array}$ & $\begin{array}{l}\text { Summer } \\
\text { crop type }\end{array}$ & Sowing time \\
\hline \multirow{3}{*}{ Rotary tillage } & Bare fallow & - & - & Maize & - \\
\cline { 2 - 6 } & Hairy vetch & 10 -Nov-16 & 24 -Apr-17 & Maize & 18 -May-17 \\
\cline { 2 - 6 } & Brown mustard & $10-$ Nov-16 & 24 -Apr-17 & Maize & 18 -May-17 \\
\hline \multirow{3}{*}{ No-tillage } & Bare fallow & - & - & Maize & - \\
\cline { 2 - 6 } & Hairy vetch & 10 -Nov-16 & 24 -Apr-17 & Maize & 18 -May-17 \\
\cline { 2 - 6 } & Brown mustard & 10 -Nov-16 & 24 -Apr-17 & Maize & 18 -May-17 \\
\hline
\end{tabular}

Table 1. Summary of cover crop types and tillage practices in the present experiment. ${ }^{\mathrm{a} D D} / \mathrm{MM} / \mathrm{YY} .{ }^{\mathrm{b}} \mathrm{A}$ hammer knife mower was used to terminate both cover crops at both tillage management systems. Rotary tillage: the aboveground plant parts of cover crops were incorporated into the soil by a rotary tiller. No tillage: the aboveground plant parts of cover crops remained on the soil surface.

indigenous AMF abundance in soil and root colonization by AMF, thus improving the growth and yield of subsequent crops $^{10,25-27}$. Furthermore, the introduction of mycorrhizal pre-crops combined with a no-tillage system increases early stage maize (Zea mays L.) growth and AMF colonization to a greater extent than that of mycorrhizal pre-crops combined with a rotary-tillage system ${ }^{28}$. Thus, combining cover crop systems with conservation tillage may provide many benefits that improve subsequent crop performance.

Moreover, there is clear evidence that AMF community structure and diversity improve plant growth performance $^{29}$. Increased AMF richness in agricultural ecosystems has been suggested to improve crop performance ${ }^{30}$, while co-inoculation of AMF taxa belonging to different families improves plant biomass and mineral nutrition more efficiently than mono-inoculation ${ }^{31-33}$. In terms of agricultural management practices, tillage ${ }^{34,35}$ and cover cropping ${ }^{27,36}$ can alter the AMF community structure and diversity in soil and roots. For instance, Oehl and Koch $^{37}$ reported AMF spore communities in conventional tillage are distinct from those in no-tillage systems in a vineyard farm, based on AMF spore morphology. Morimoto et al. ${ }^{38}$ showed that AMF communities in the roots of subsequent soybean crops differed, depending on their rotation with winter wheat or fallow. Other studies have shown that AMF communities can be shaped in subsequent crops, and the effect of the identity of the host crop is stronger than that of the cover crops ${ }^{27,39,40}$. Aside from these conflicting results, most other studies have investigated only the impact of cover cropping on AMF communities in subsequent crops $^{27,39,40}$ and there is a lack of information about the impacts on AMF communities in subsequent crops under different agricultural management systems, such as the combination of cover cropping with tillage systems. Given our lack of knowledge regarding AMF communities in combined cover crop rotations with different tillage systems, it is imperative to understand how combining cover cropping with different tillage systems change AMF communities in subsequent crops using next-generation sequencing techniques (Illumina MiSeq Platform, etc.).

It is currently unclear which factor, cover cropping or tillage, has a greater influence in the shifts in the AMF communities in the roots of subsequent crops under cover crop rotational systems. Little is also known about how the combination of cover cropping with different types of tillage (rotary tillage and no tillage) drives shifts in the AMF communities in the roots of subsequent crops. Knowing whether such management affects the soil status and its connections to AMF taxa may help to determine the proper practices under specific agricultural settings. We hypothesized that:

1. The AMF communities of subsequent crops in cover cropping combined with rotary tillage are distinct from those in cover cropping combined with no tillage.

2. The AMF communities of subsequent crops in a rotary-tillage system will have relatively more taxa that can tolerate stress in the presence of disturbance compared to those in a cover cropping system combined with no tillage.

Illumina amplicon sequencing is a commonly used and helpful technique for AMF community analysis ${ }^{41-45}$. Thus, we used this technique to investigate how and whether AMF communities in the roots of maize crops change in different types of cover cropping systems combined with rotary or no tillage.

\section{Materials and Methods}

Experimental design of the field experiment. We performed a cover crop-maize rotational study at a Nihon University research field in Kanagawa, Japan. The research field soil is classified as an Allophonic andosol (volcanic ash soil). We combined two different cover crops [hairy vetch (Vicia villosa Roth., var. Fujiemon) and brown mustard (Brassica juncea (L.) Czern \& Coss., var. Karajin)] and one bare fallow treatment with rotary or no tillage as our experimental design (Table 1). The treatments were rotated annually with maize (var. P1690). All plots had dimensions of $4 \mathrm{~m} \times 5 \mathrm{~m}$ with three replicates, arranged according to a randomized complete block design. Regardless of tillage management, on November 10, 2016, we used a drill-seeder to plant the two cover crops at a spacing of $40 \mathrm{~cm}$ in rows. On April 24, 2017, we terminated both cover crops using a hammer knife mower (HRC662B, Iseki Co., Ltd., Ehime, Japan) and the aboveground parts of both cover crops remained on the soil surface in the no-tillage system. In the rotary-tillage plot, the aboveground plant parts were incorporated into the soil using a rotary tiller (KRA850, Kubota Co., Ltd., Osaka, Japan). After cover cropping or bare fallow treatment with or without rotary tillage, we planted maize at a spacing of $75 \mathrm{~cm} \times 20 \mathrm{~cm}$ on May 18,2017 . After planting maize, each treatment received $\mathrm{N}, \mathrm{P}_{2} \mathrm{O}_{5}$, and $\mathrm{K}_{2} \mathrm{O}$ at the rate of 200,150 , and $200 \mathrm{~kg} \mathrm{ha}^{-1}$, respectively. 
Soil and root collection, and root staining procedure. Soil samples in each plot comprised 10 soil cores ( $4 \mathrm{~cm}$ diameter, $0-20 \mathrm{~cm}$ depth) randomly collected using a core sampler (DIK-102A, Daiki Rika Co., Ltd., Saitama, Japan). On May 17, 2017, we pooled the soil samples into one composite soil sample. The roots of maize crops were collected at the stage of eight fully emerged leaves (V8 stage) on July 3, 2017. We collected maize root samples from nine plants (15-cm diameter, $0-20 \mathrm{~cm}$ depth) per plot. After collecting the root samples, we stored them at $-80^{\circ} \mathrm{C}$ for subsequent staining and DNA extraction. The roots were stained with a $3,3^{\prime}$-diaminobenzidine (DAB) solution ${ }^{46}$, and we counted AMF colonization according to Giovannetti and Mosse ${ }^{47}$.

Measurement of soil biochemical properties. Soil biochemical properties were measured after cover cropping. We analyzed soil $\mathrm{pH}$ (soil:water ratio of $1: 2.5 \mathrm{w} / \mathrm{v}$ ) with a digital $\mathrm{pH}$ and conductivity meter (HI 9811, HANNA), and soil nitrate-nitrogen $\left(\mathrm{NO}_{3}-\mathrm{N}\right)$ content was measured using a LAQUA Twin nitrate meter (Horiba, Ltd., Kyoto, Japan). Extractable P (available P) from all soils, regardless of tillage management, was obtained as previously described ${ }^{48}$ and measured using molybdenum blue method at $710 \mathrm{~nm}$ using a UV-1700 Spectrophotometer (Shimadzu Co. Ltd., Japan). Soil acid phosphatase (ACP), alkaline phosphatase (ALP), and $\beta$-glucosidase activities in the soils were measured according to Ishii and Hayano ${ }^{49}$ and Hayano ${ }^{50}$.

Processing of samples for amplicon sequencing. We froze $100 \mathrm{mg}$ of fresh maize roots from all plots and retrieved total genomic DNA from the roots using the DNA suisui-P kit (RIZO, Tsukuba, Japan) ${ }^{27}$ following the manufacturer's instructions. DNA solution was stored at $-30^{\circ} \mathrm{C}$ until use. For nested PCR, we targeted a partial sequence of the small subunit of the ribosomal RNA gene (SSU rDNA) region using a previously described PCR method ${ }^{27}$. We selected the primer pair $A M 1^{51} / N S 31^{52}$ for the first PCR to amplify a partial region of the $18 \mathrm{~S}$ rDNA of AMF taxa. The first PCR was performed in $10-\mu$ l reactions, each consisting of $2 \times$ Platinum $^{\mathrm{TM}} \mathrm{Green}$ Master Mix (Thermo Fisher Scientific Inc), $1 \mu \mathrm{l}$ of template DNA, and $0.4 \mu \mathrm{M}$ of AM1/NS31 primers. For the second PCR procedure, we diluted the amplicons from the first PCR 10-fold and used these amplicons as a template for the AMV4.5NF/AMDGR ${ }^{53}$ primers that are attached via the Illumina MiSeq adapter sequences. The second PCR was performed in $10 \mu \mathrm{l}$ reactions comprising $1 \mu \mathrm{l}$ of template DNA, $2 \times$ Platinum $^{\text {TM }}$ Green Master Mix, and $0.3 \mu \mathrm{M}$ of AMV4.5NF/AMDGR primers. Then we added both the Illumina MiSeq adapter sequences and an 8-bp barcode sequence as an index to distinguish each PCR amplicon.

Miseq amplicon sequencing of AMF communities in roots. The Illumina MiSeq amplicons were sequenced to determine AMF communities in the roots of maize crops following procedures reported by Higo et $a l^{27,54}$. Briefly, we washed and cleaned the amplicons from the second PCR before amplicon sequencing. These products were paired-end $(\mathrm{PE})$ sequenced $(2 \times 300 \mathrm{bp})$ using an instrument of Illumina MiSeq amplicon sequencing at the Bioengineering Lab Co., Ltd. We performed the processing of sequence reads using QIIME version 1.9. $1^{55}$. The PE reads were truncated at any site that received an average quality score of $<20$ over a 40 -bp sliding window, and truncated reads shorter than $40 \mathrm{bp}$ were discarded using the FASTX-Toolkit (http://hannonlab. cshl.edu/fastx_toolkit/index.html). We assembled the PE reads through their overlapping sequences that had a minimum overlap length of $10 \mathrm{bp}$ and we deleted the reads that could not be assembled. We used Fast length adjustment of short reads (FLASH) ver. 1.2.11 to assess the clean sequences. Chimeric sequences were removed using UCHIME in USEARCH ver. 10.0.240. We then utilized the BLAST function in the MaarjAM database (https://maarjam.botany.ut.ee/) to determine and group the operational taxonomic units (OTUs) at $97 \%$ similarity. Additional taxonomic assignment was based on phylogenetic relationships. Representative sequences were aligned with known AMF taxa from NCBI Genbank and a neighbor-joining phylogenetic tree with 1000 bootstrap replicates was created using MEGA $7^{56}$ (see Supplementary Fig. S1). The raw data sequences have been deposited at the Sequence Read Archive of the DNA Data Bank of Japan (DDBJ) under Bio Project Accession number PRJDB7275.

Statistical analysis. Root staining data reflecting AMF colonization was transformed into the arcsine-square root values for normalization. The differences in the mean values of each parameter among tillage and cover cropping systems were evaluated by Tukey's test and then two-way analysis of variance (ANOVA) was conducted using the emmeans ${ }^{57}$ package in R 3.6.1 (www.r-project.org). Before molecular bioinformatic analysis, we resampled according to the lowest number of reads to equalize the assessment among all treatments regardless of Illumina amplicon read depth. After rarefaction analysis, we calculated the Hill number 0D as OTU richness $(q=0)$, the Shannon index (the exponential of Shannon entropy, $q=1$ ), and the Simpson index (the inverse Simpson concentration, $\mathrm{q}=2$ ) from data on the diversity of AMF communities using the "renyi" function ${ }^{58}$ of the vegan package ${ }^{59}$. Additionally, to test whether AMF OTUs were significantly related to rotary tillage and no tillage with cover cropping, we performed a species indicator analysis. We also estimated values of indicator species using "multipatt" function ${ }^{60}$ in the indicspecies package to test for statistical significance of the highest OTU association in each plot.

To demonstrate the variations in the AMF communities in maize crops among tillage management and cover cropping, we performed distance-based redundancy analysis (db-RDA) in the vegan package in R.3.6.1 $1^{59}$. Goodness-of-fit $\left(R^{2}\right)$ for measured factors fitted to the db-RDA ordination of the AMF communities were calculated using the "envfit" function in the vegan package with $P$-values based on 999 permutations ${ }^{59}$. A permutational multivariate analysis of variance (PERMANOVA) was performed with 9999 permutations using the "adonis" function in the vegan package to investigate if AMF communities differed significantly in tillage management and cover cropping. In addition, a multinomial species classification method $^{27,61}$ using the package vegan were introduced to recognize "specialist OTUs" and "generalist OTUs" for tillage or no tillage. 


\begin{tabular}{|c|c|c|c|c|c|c|c|c|c|c|}
\hline \multirow[b]{2}{*}{ Plots } & \multirow{2}{*}{\begin{tabular}{|l|}
$\mathrm{pH}$ \\
$\left(\mathrm{H}_{2} \mathrm{O}\right)$
\end{tabular}} & \multirow{2}{*}{\begin{tabular}{|l|}
$\mathrm{NO}_{3}-\mathrm{N}$ \\
$(\mathrm{mg} / \mathrm{kg})$
\end{tabular}} & & \multirow{2}{*}{\begin{tabular}{|l|} 
Available P \\
$(\mathbf{m g ~ P} / \mathrm{kg})$
\end{tabular}} & \multirow{2}{*}{\begin{tabular}{|l|}
$\begin{array}{l}\text { ACP } \\
\text { activity }\end{array}$ \\
$(\mathrm{mU} / \mathrm{g})$ \\
\end{tabular}} & & \multirow{2}{*}{\begin{tabular}{|l|}
$\begin{array}{l}\text { ALP } \\
\text { activity }\end{array}$ \\
$(\mathrm{mU} / \mathrm{g})$ \\
\end{tabular}} & & \multirow{2}{*}{\begin{tabular}{|l|}
$\begin{array}{l}\beta \text {-glucosidase } \\
\text { activity }\end{array}$ \\
$(\mathrm{mU} / \mathrm{g})$ \\
\end{tabular}} & \\
\hline & & & & & & & & & & \\
\hline RT + Fallow $^{\mathrm{a}}$ & $5.4 \pm 0.03^{\mathrm{b}}$ & $30.5 \pm 2.0$ & & $67.7 \pm 22.4$ & $13.9 \pm 0.8$ & & $29.5 \pm 0.5$ & & $3.7 \pm 0.1$ & $c^{d}$ \\
\hline $\begin{array}{l}\text { RT + Brown } \\
\text { mustard }\end{array}$ & $5.3 \pm 0.09$ & $51.0 \pm 6.5$ & & $53.3 \pm 10.1$ & $20.7 \pm 0.6$ & & $32.5 \pm 1.9$ & & $8.2 \pm 0.7$ & $b c$ \\
\hline RT + Hairy vetch & $5.2 \pm 0.06$ & $67.8 \pm 11.3$ & & $52.0 \pm 19.5$ & $23.7 \pm 2.4$ & & $36.0 \pm 1.2$ & & $11.3 \pm 1.1$ & $\mathrm{~b}$ \\
\hline NT + Fallow & $5.4 \pm 0.09$ & $35.4 \pm 3.3$ & & $15.4 \pm 3.1$ & $14.2 \pm 0.4$ & & $28.4 \pm 1.4$ & & $3.2 \pm 0.1$ & c \\
\hline $\begin{array}{l}\mathrm{NT}+\text { Brown } \\
\text { mustard }\end{array}$ & $5.2 \pm 0.03$ & $43.1 \pm 12.3$ & & $20.3 \pm 4.3$ & $19.1 \pm 1.3$ & & $37.1 \pm 1.7$ & & $7.4 \pm 1.0$ & $b c$ \\
\hline NT + Hairy vetch & $5.4 \pm 0.11$ & $64.0 \pm 1.9$ & & $36.1 \pm 4.5$ & $19.4 \pm 1.2$ & & $38.0 \pm 1.9$ & & $18.9 \pm 3.5$ & $\mathrm{a}$ \\
\hline Rotary tillage & $5.3 \pm 0.04$ & $59.8 \pm 13.5$ & & $57.7 \pm 9.4$ & $19.4 \pm 1.6$ & & $32.7 \pm 1.2$ & & $7.7 \pm 1.2$ & \\
\hline No tillage & $5.3 \pm 0.05$ & $47.5 \pm 5.7$ & & $24.0 \pm 3.7$ & $17.6 \pm 1.0$ & & $34.5 \pm 1.7$ & & $9.8 \pm 2.6$ & \\
\hline Fallow & $5.4 \pm 0.05$ & $33.0 \pm 2.1$ & $B^{c}$ & $41.6 \pm 15.5$ & $14.1 \pm 0.4$ & B & $29.0 \pm 0.7$ & B & $3.4 \pm 0.1$ & B \\
\hline Brown mustard & $5.3 \pm 0.04$ & $47.1 \pm 6.5$ & B & $36.8 \pm 8.9$ & $19.9 \pm 0.7$ & A & $34.8 \pm 1.6$ & A & $7.8 \pm 0.6$ & B \\
\hline Hairy vetch & $5.3 \pm 0.08$ & $65.0 \pm 2.7$ & A & $44.1 \pm 9.6$ & $21.5 \pm 1.6$ & A & $37.0 \pm 1.1$ & A & $15.1 \pm 2.4$ & A \\
\hline \multicolumn{11}{|c|}{ Two-way ANOVA } \\
\hline Tillage (A) & n.s. & n.s. & & $P<0.01$ & n.s. & & n.s. & & n.s. & \\
\hline $\begin{array}{l}\text { Cover cropping } \\
\text { (B) }\end{array}$ & n.s. & $P<0.01$ & & n.s. & $P<0.001$ & & $P<0.001$ & & $P<0.001$ & \\
\hline $\mathrm{A} \times \mathrm{B}$ & n.s. & n.s. & & n.s. & n.s. & & n.s. & & $P<0.05$ & \\
\hline
\end{tabular}

Table 2. Influence of cover crops and tillage management on the soil biochemical properties before planting maize. ${ }^{a} \mathrm{RT}$ : rotary tillage. NT: no tillage. ${ }^{b}$ Means \pm standard errors. ${ }^{c}$ Different capital letters within the same column for $\mathrm{NO}_{3}-\mathrm{N}$ content, activities of acid, alkali phosphatase and $\beta$-glucosidase among mean values of three cover crop types indicate significant differences at the $5 \%$ level by the Tukey test. ${ }^{\mathrm{d}}$ Different lower letters within the same column for $\beta$-glucosidase activity among each treatment indicate significant differences at the $5 \%$ level by the Tukey test. ${ }^{\mathrm{e}} \mathrm{A}$ significant difference at the $5 \%, 1 \%$ and $0.1 \%$ levels by cover cropping and tillage practices were explained by two-way analysis of variance. All analyses were run in the software environment RStudio (Version 1.2.1335 - (c) 2009-2019 RStudio, Inc.) (http://www.rstudio.com).

\section{Results}

Soil biochemical properties and AMF colonization of maize roots among different cover cropping practices with rotary or no tillage. Two-way ANOVA shows that the $\mathrm{NO}_{3}-\mathrm{N}$ content in soil was significantly influenced by cover cropping, but soil $\mathrm{pH}$ was not affected by either tillage or cover crop management (Table 2). The two-way ANOVA allows interpretation of main effects and interaction, therefore, we performed the Tukey test only in the measured variables that there was a significant difference by cover crop management. In particular, the average $\mathrm{NO}_{3}-\mathrm{N}$ content for hairy vetch was significantly higher than those in other cover crops. The available soil $\mathrm{P}$ was higher in all rotary tilled treatments than in no tilled ones. Conversely, the activity of ACP, ALP, and $\beta$-glucosidase in soil was significantly affected by cover cropping. The activity of average ACP and ALP for hairy vetch and brown mustard was significantly higher than that in fallow. The activity of average $\beta$-glucosidase showed a similar trend, but a significant effect of tillage was observed in hairy vetch, where the activity raised in no tilled treatment, in opposition to fallow and brown mustard, where remained unchanged. A significant difference in the colonization by AMF among other cover crop treatments regardless of tillage management was not detected (Fig. 1).

Maize root AMF community taxa after cover cropping with tillage systems. We detected a total of 148 AMF OTUs in the roots of maize (Fig. 2 and Supplementary Table S1). Regardless of tillage management, the Hill numbers did not differ significantly, including AMF OTU richness, Shannon index (the exponential of Shannon entropy), and Simpson index (the inverse Simpson concentration) among cover cropping systems (Fig. 3A-C). Moreover, the relative abundance of AMF OTUs did not differ significantly among cover cropping treatments with or without rotary tillage (Fig. 4A and Supplementary Table S2A). Overall, Glomus and Rhizophagus genera were the most abundant in maize roots (average of $45.9 \%$ and $43.8 \%$, respectively) (Fig. $4 \mathrm{~B}$ and Supplementary Table S2B). The relative abundance levels of Claroideoglomus and Cetraspora genera were $5.3 \%$, and $2.3 \%$, respectively. We also found relatively low abundance levels of Gigaspora, Racocetra, Scutellospora, Acaulospora, Dentiscutata, and Funneliformis in the roots of maize crops $(1.2 \%, 0.6 \%, 0.6 \%, 0.1 \%, 0.1 \%$, and $0.02 \%$, respectively).

Generalist taxa were represented by $66.7 \%$ of the OTUs that were commonly shared in the roots of maize crops undergoing both tillage and no-tillage treatments (Fig. 5 and Supplementary Table S3). In total, 10.7\% and 18.7\% of the AMF OTUs were unique to only rotary tillage or no tillage, respectively. Our assessment of the values of indicator species suggests that six AMF taxa are indicators that were significantly affected by tillage management; these mainly include Glomus and uncultured Glomeromycotina taxa in the rotary-tillage system (Supplementary Table S4).

Differences in AMF OTU communities of maize roots. Among rotary-tillage treatments, bare fallow (Monte-Carlo permutation test: $R^{2}=0.681, P$-value $\left.=0.024\right)$ and brown mustard $\left(R^{2}=0.837, P\right.$-value $=0.013$ ) 


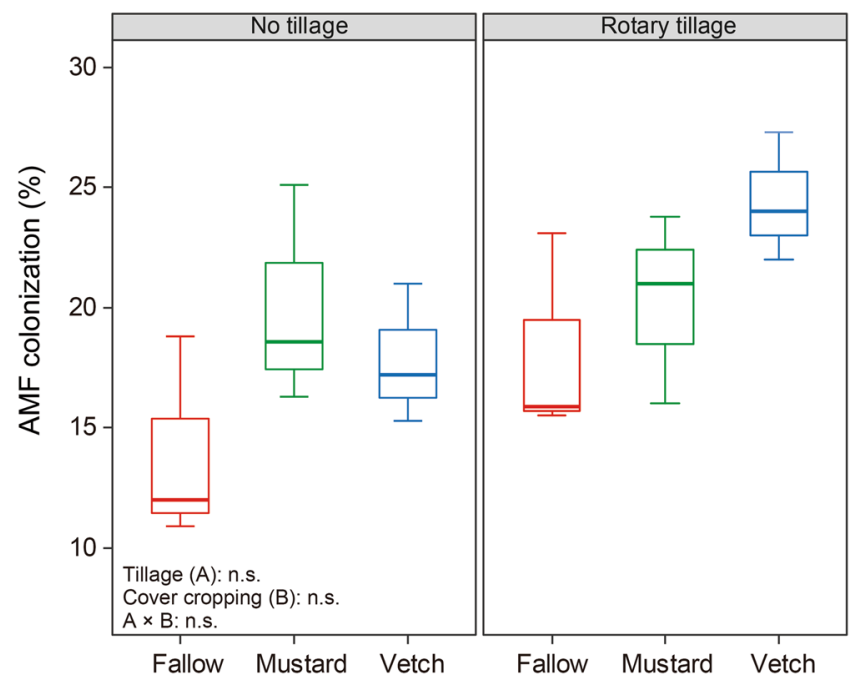

Figure 1. Influence of cover crops and tillage management on the colonization of arbuscular mycorrhizal fungi (AMF) in maize roots at the eight fully emerged leaves stage. Horizontal bold lines explain the median number; vertical lines explain minimum and maximum numbers of the plots and box margins \pm standard errors. n.s. indicates no significant difference by two-way analysis of variance. All analyses and Fig. 1 were run and created in the software environment RStudio (Version 1.2.1335 - (c) 2009-2019 RStudio, Inc.) (http://www.rstudio.com).

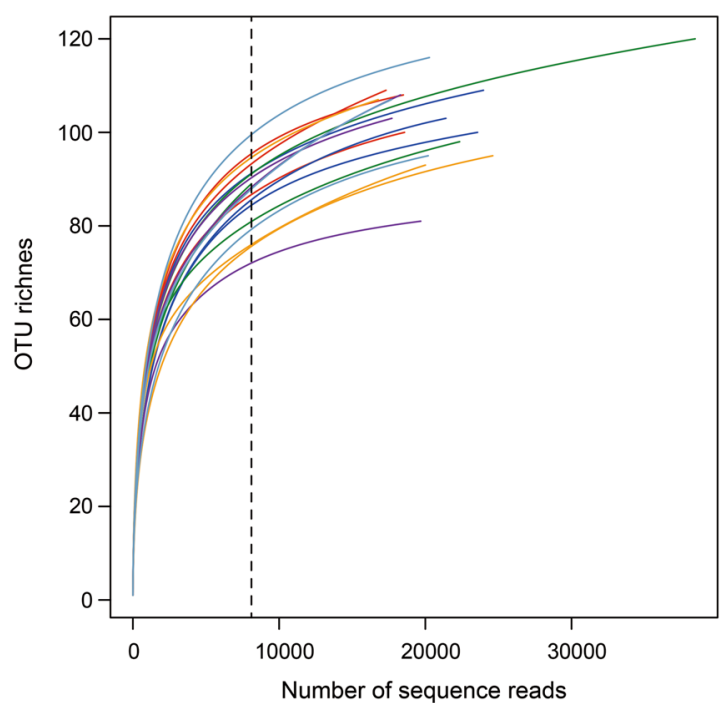

Figure 2. Depths of Illumina amplicon sequencing in the maize roots by rarefaction analysis. The vertical dashed line was placed at 8,104 sequences and the operational taxonomic units (OTUs) of arbuscular mycorrhizal fungi (AMF) were defined at a cut-off level of 8,104 reads. All analyses and Fig. 2 were run and created in the software environment RStudio (Version 1.2.1335 - (c) 2009-2019 RStudio, Inc.) (http://www. rstudio.com).

significantly affected the AMF communities (Fig. 6A), while hairy vetch $\left(R^{2}=0.395, P\right.$-value $\left.=0.233\right)$ did not affect the AMF communities of maize crops. Among the no-tillage treatments, only brown mustard $\left(R^{2}=0.650\right.$, $P$-value $=0.031)$ significantly affected the AMF communities (Fig. 6B). Among the rotary-tillage treatments, PERMANOVA reveals that the cover crop treatment significantly affected the AMF communities of maize crops (PERMANOVA: $F$-statistic $=2.025, P$-value $=0.014$ ). However, cover crops did not significantly affect the AMF communities in no-tillage treatments $(F$-statistic $=0.738, P$-value $=0.902)$.

The db-RDA also found that tillage management alters the AMF communities of maize crops, while only brown mustard pre-crop significantly affected the AMF communities (Monte-Carlo permutation test: $R^{2}=0.507, P$-value $\left.=0.002\right)($ Fig. 7$)$. Both rotary tillage $\left(R^{2}=0.515, P\right.$-value $\left.=0.007\right)$ and no tillage $\left(R^{2}=0.515\right.$, $P$-value $=0.007)$ had significant effects on the AMF communities in maize crops. Moreover, PERMANOVA shows that tillage management rather than cover cropping or the interaction between tillage management and cover crop type significantly affected the AMF communities in maize crops (PERMANOVA: $F$-statistic $=1.897$, $P$-value $=0.037)$. 

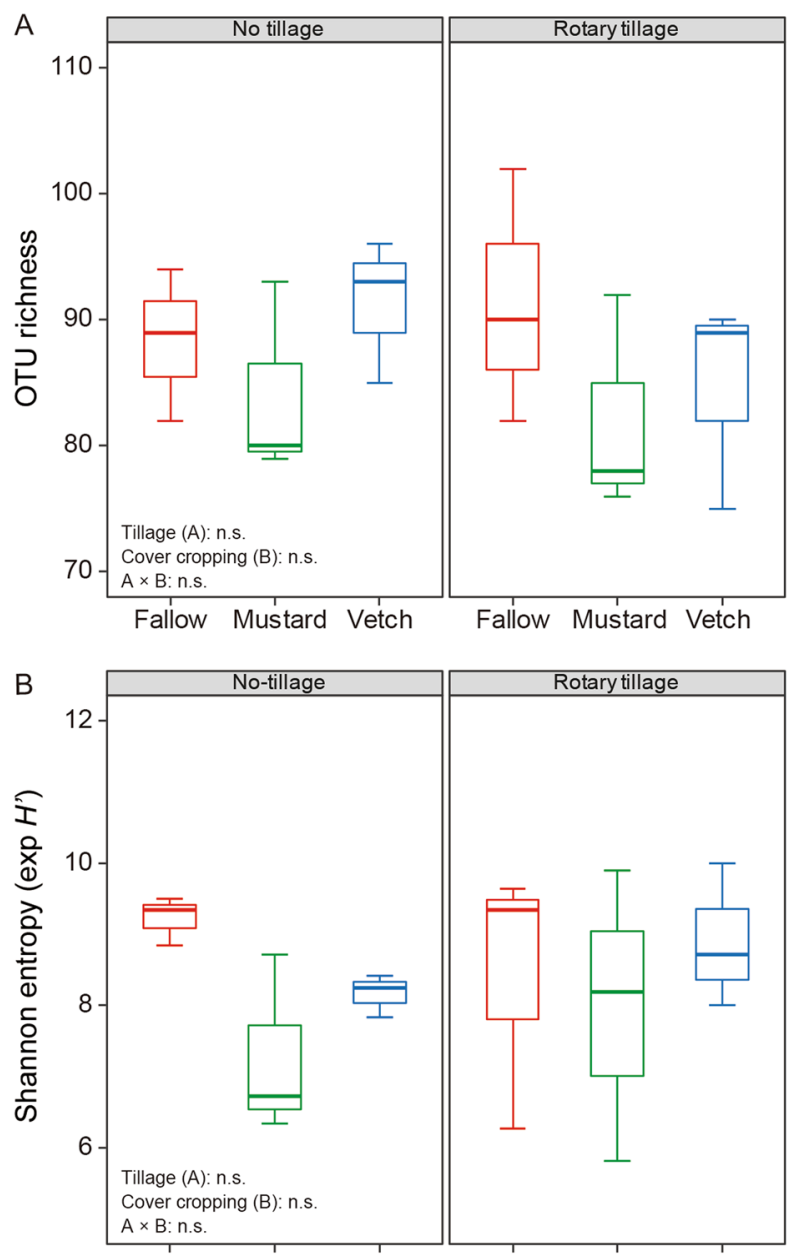

Fallow Mustard Vetch Fallow Mustard Vetch

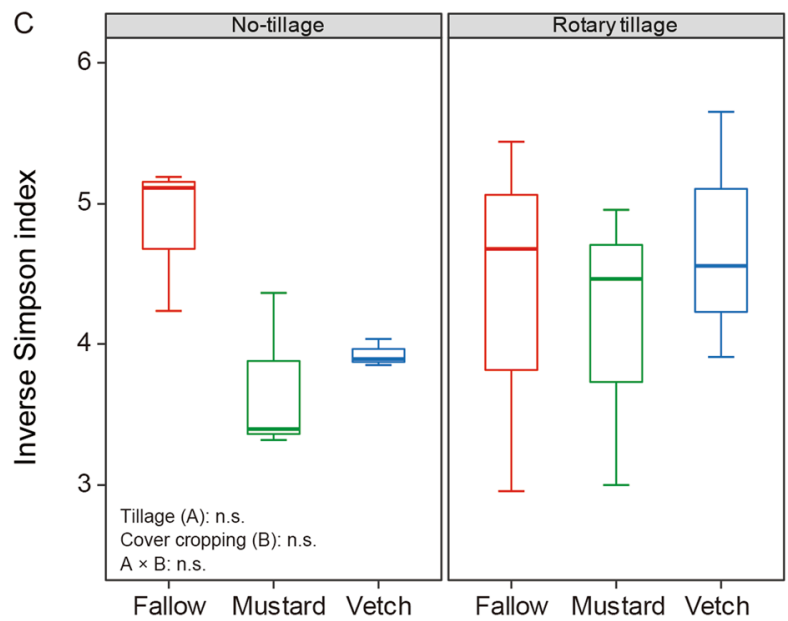

Figure 3. Influence of cover crops and tillage management on the Hill numbers in the maize roots at the eight fully emerged leaves stage. (A) The Hill number 0D as operational taxonomic unit (OTU) richness, (B) Shannon index (the exponential of Shannon entropy), and (C) Simpson index (the inverse Simpson concentration). n.s. means no significant differences by two-way analysis of variance. Horizontal bold lines explain the median number; vertical lines explain minimum and maximum numbers in the plots and box margins \pm standard errors. n.s. indicates no significant difference by two-way analysis of variance. All analyses and Fig. 3 were run and created in the software environment RStudio (Version 1.2.1335 - @ 2009-2019 RStudio, Inc.) (http://www. rstudio.com). 

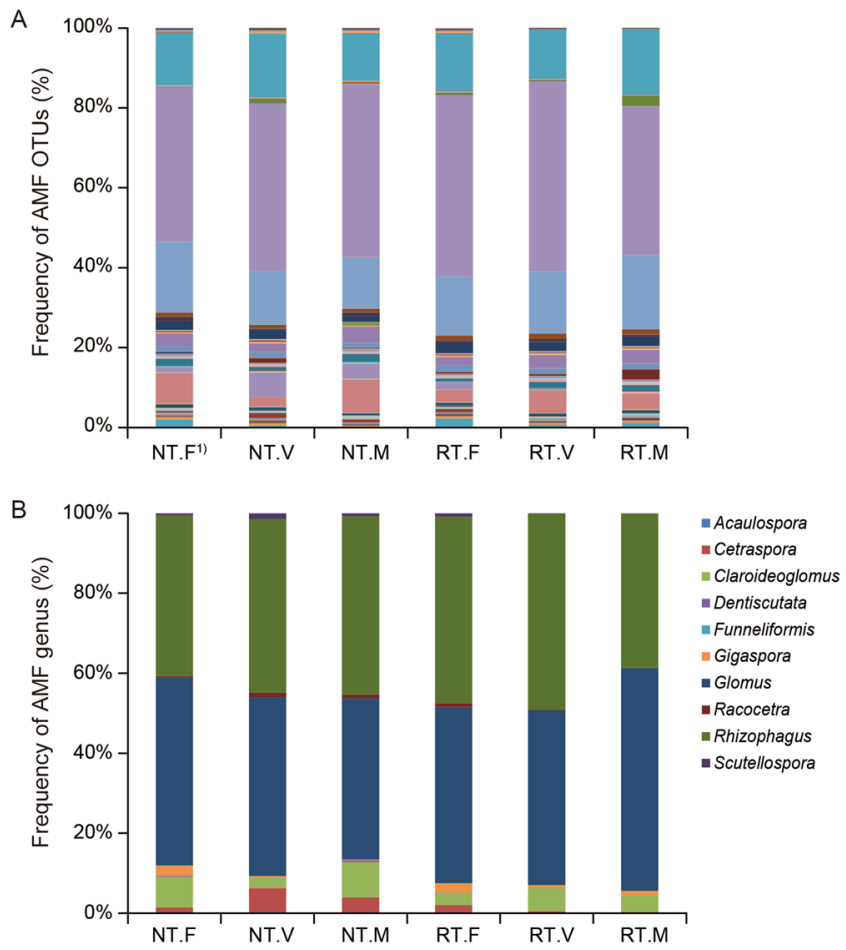

Figure 4. Relative abundance of operational taxonomic units (OTUs) and genus of arbuscular mycorrhizal fungi (AMF) in the maize roots at the eight fully emerged leaves stage. 1) RT: rotary tillage, NT: no tillage. F: fallow, M: brown mustard, V: hairy vetch. A = OTU-based abundance, $\mathrm{B}=$ genus-based abundance.

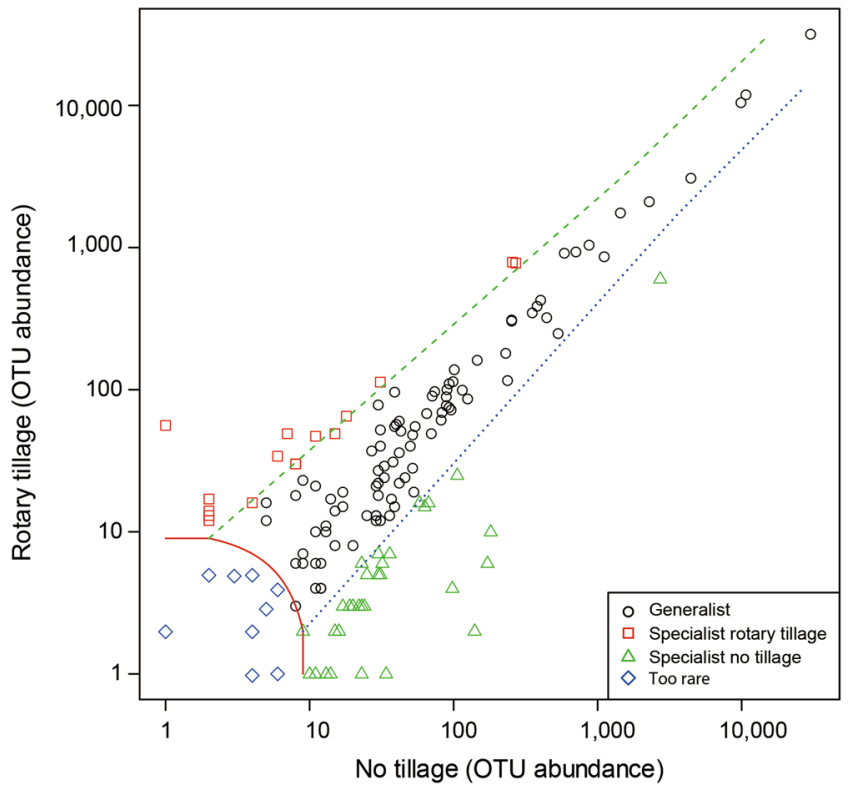

Figure 5. Multinomial species classification of taxa in the maize roots grown under rotary tillage and no tillage. The operational taxonomic units (OTUs) of arbuscular mycorrhizal fungi (AMF) common to both rotary tillage and no tillage are represented by circles; those observed only in rotary tillage are represented by squares, and those observed only in no tillage are represented by triangles. Diamonds represent rare AMF OTUs. All analyses and Fig. 5 were run and created in the software environment RStudio (Version 1.2.1335 - () 2009-2019 RStudio, Inc.) (http://www.rstudio.com).

\section{Discussion}

AMF communities in maize roots. Our findings indicate that representatives of Glomeraceae (Glomus and Rhizophagus) and Claroideoglomeraceae (Claroideoglomus) are the main genera in maize roots (Fig. 4B and 
A

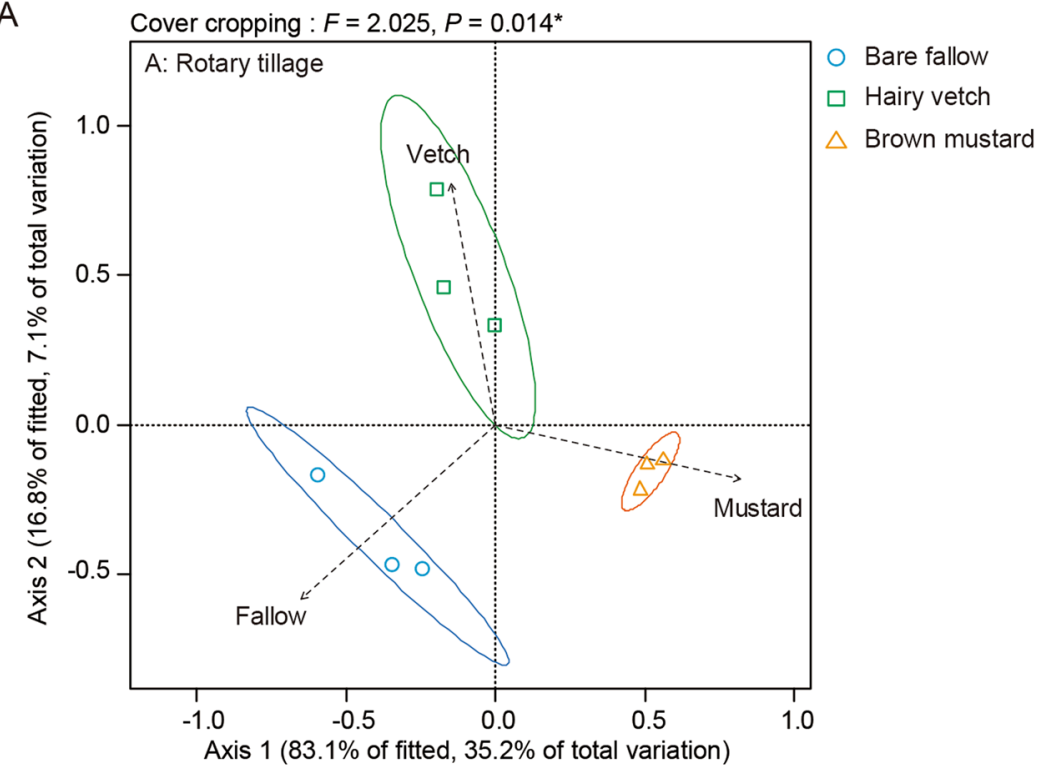

B

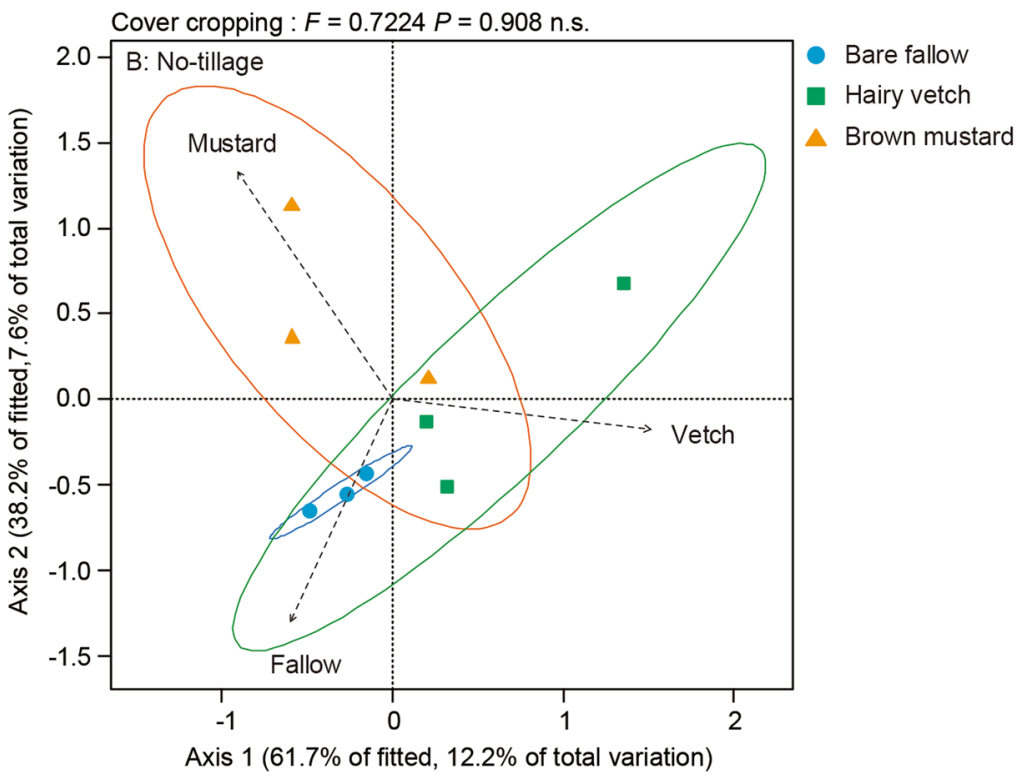

Figure 6. Distance-based redundancy analysis (db-RDA) of the influence of cover crop type in each tillage management system on the communities of arbuscular mycorrhizal fungi (AMF) in the maize roots. Dashed lines explain the effect of each type of cover crop. Ellipses represent $95 \%$ confidence intervals. A: rotary tillage, B: no tillage. All analyses and Fig. 6 were run and created in the software environment RStudio (Version 1.2.1335 - () 2009-2019 RStudio, Inc.) (http://www.rstudio.com).

Supplementary Table S1). Current reports based on Illumina amplicon sequencing have shown that Glomeraceae taxa are generally dominant under agricultural field conditions ${ }^{41-45,54}$ because of their abilities to sporulate for rapid recovery and to adapt to disturbed environments ${ }^{62}$. Moreover, Glomeraceae are able to colonize through fragments of mycelium or through root fragments containing mycorrhizae ${ }^{63}$. Their hyphae are able to easily anastomose owing to their ability to re-establish a network after a mechanical disruption ${ }^{64}$. In contrast, members of Gigasporaceae, such as Cetraspora, Gigaspora, Scutellospora, Racocetra, and Dentiscutata, propagate through spore dispersal or through intact hyphae ${ }^{65-67}$. These factors taken together explain why Glomeraceae is generally dominant in cultivated lands, that is, it is well-adapted to agricultural settings. Additionally, PCR-based AMF community findings may also be affected by PCR bias, which is dependent on different combinations of the primer pair with the target region of the rRNA gene that are due to potentially different degrees of specificity and amplification efficiency ${ }^{68}$. For example, Kohout et al.$^{68}$ reported that primer pairs that target the SSU and large subunit (LSU) rDNA of AMF are strongly biased toward Glomeraceae. Because our results show that Glomeraceae are dominant in maize roots regardless of tillage and cover cropping, further studies should carefully select primer pairs that avoid potential PCR and primer bias as well as technical sequencing errors. 


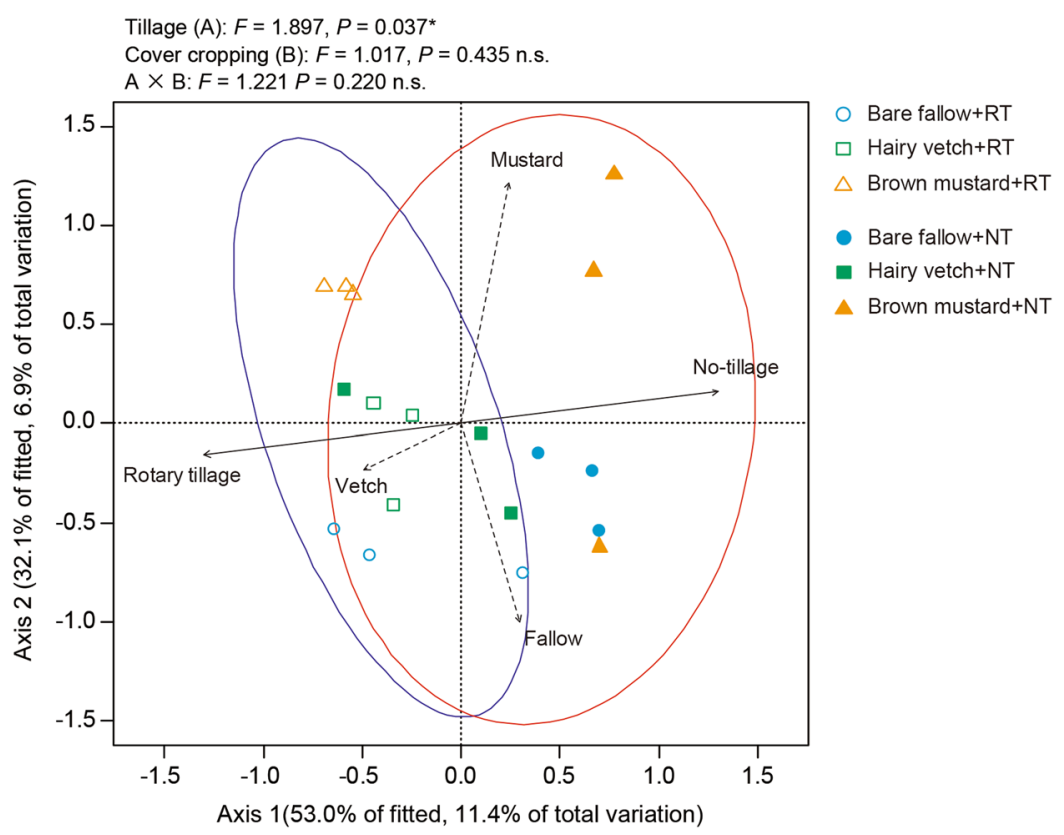

Figure 7. Influence of cover crop type and tillage management on the communities of arbuscular mycorrhizal fungi (AMF) in the maize roots according to distance-based redundancy analysis (db-RDA). Dashed lines explain the effect of each type of cover crop. RT: rotary tillage. NT: no tillage. Ellipses represent $95 \%$ confidence intervals. All analyses and Fig. 7 were run and created in the software environment RStudio (Version 1.2.1335(C) 2009-2019 RStudio, Inc.) (http://www.rstudio.com).

In addition, environmental factors may shape the AMF communities ${ }^{69}$. For example, Gottshall et al. ${ }^{69}$ suggested that Gigasporaceae tends to be associated with soil disturbance, but the association is not statistically significant. Conversely, $R$. irregularis of the Glomeraceae, which is recognized as a generalist, has been discovered in different land-use types and can tolerate different agricultural practices, including tillage due to its ability to rapidly reconstruct its hyphal network ${ }^{70}$. However, intensive agricultural management practices may both simplify and shape the AMF communities according to AMF taxa preferences ${ }^{35,69}$. These findings indicate that the frequencies of AMF specialists and generalists within the AMF communities may change according to tillage intensity ${ }^{18}$. The shifts that we observed in the AMF OTUs (Figs. 4 and 5 and Supplementary Tables S2-S4) may be connected to the preference of AMF taxa in the roots of maize crops for tillage or cover cropping practices.

Influence of tillage and cover crops on shifts in AMF communities. The beneficial impacts of cover cropping may differ among the AMF communities, and the question of whether cover crop type changes the AMF communities in the roots of maize crops remains to be investigated. Higo et al. ${ }^{71}$ reported that the pre-crop type influences maize root AMF communities, which agrees with part of the present study's findings (Fig. 6). However, our findings suggest that cover cropping may not induce differences in the AMF communities in the subsequent maize crops as strongly tillage management (Fig. 7). This also agrees with data of Higo et al. ${ }^{72}$, who reported that rotation year was a stronger driver in the formation of root AMF communities in subsequent soybean crops during a 5-year cover cropping system. This indicates that climate conditions and/or some other environmental driver(s) may be the key in shaping AMF communities in roots.

In addition, AMF communities in maize crops varied distinctly, indicating that tillage practice altered the AMF communities in maize crops (Fig. 6), in partial agreement with previous data ${ }^{73,74}$. Moreover, tillage management induced more changes to the AMF communities in maize roots than the type of cover crops. However, the questions of how and whether the level of tillage intensity alters the AMF communities in agricultural settings remain unanswered. Future studies on the interactions between the AMF communities and agricultural settings should focus on how tillage intensity affects the AMF communities in maize crops rotated with cover crops.

Environmental influences on shifts in AMF communities. Tillage and cover crop residue management are particularly imperative for controlling plant-microbe interactions and crop performance ${ }^{75,76}$. In general, cover crop residues that have been incorporated into the soil surface by conventional tillage systems release allelopathic substances that can inhibit weed germination, establishment, and growth ${ }^{77}$. In contrast, in conservation tillage systems (including no tillage and reduced tillage), the nutrients from surface-broadcasted fertilizers and surface-applied crop residues accumulate and concentrate in the topsoil, where their movements are reduced $^{78}$. In no-tillage systems, however, crop residue decomposition rates and nutrient release into the soil are slow compared to conventional tillage systems, including rotary tillage and chisel plow ${ }^{79}$, which may influence the soil microbial community structures $^{80}$. These combined findings indicate that the differences between the effects of rotary and no-tillage management systems on the AMF communities in the roots of maize crops can be explained by cover crop residues releasing allelopathic substances and nutrients due to enhanced decomposition rates (Fig. 7). 
Moreover, tillage can affect soil temperature by changing soil surface conditions ${ }^{81}$. Crop residues remaining on the soil surface in conservation tillage systems, including no tillage and reduced tillage, can decrease the rate of soil temperature fluctuations because the surface residues reflect incident solar radiation more than the bare soil $^{82}$. A previous study shows that soil temperature changes both the structure and allocation of the AMF hyphal network; this effect is consistent in cooled soils (soil temperature $14^{\circ} \mathrm{C}$ ), ambient soils $\left(20^{\circ} \mathrm{C}\right.$ ), and warmed soils $\left(26^{\circ} \mathrm{C}\right)^{83}$. Heinemeyer et al..$^{84}$ reported that shading and soil temperature changed AMF communities in roots, with some AMF taxa being replaced (although inconsistently) by others and some disappearing throughout winter, summer and autumn. Higo et al. ${ }^{85}$ also reported on seasonal variation, finding a distinct difference between winter and spring AMF communities in the roots of winter cover crops. However, we did not investigate the effect of tillage systems and cover crop residues on soil temperature fluctuations. Future research should investigate how and whether AMF communities respond to environmental changes due to cover cropping and tillage management systems.

\section{Conclusions}

Tillage management may be more important than cover cropping in shaping the AMF communities in maize crops. In addition, various kinds of cover cropping systems may produce various types of effects on the AMF communities in maize crop roots. The synergistic effects of tillage and cover cropping are partially responsible for shaping the AMF communities. Knowledge in this connection should be valuable in future experiments. This is because variations in the AMF communities in roots may influence crop growth performance in cropping systems with tillage management. However, we still need to clarify how the combination of tillage intensity and cover crop type is associated with individual AMF taxa in agricultural settings. Such an investigation will provide beneficial information on the appropriate cover crop selection and tillage practice for improving the functions of AMF taxa in cropping systems.

Received: 24 August 2019; Accepted: 22 January 2020; Published online: 03 April 2020

\section{References}

1. Williams, A. et al. Soil water holding capacity mitigates downside risk and volatility in US rainfed maize: time to invest in soil organic matter? Plos One 11, e0160974, https://doi.org/10.1371/journal.pone.0160974 (2016).

2. Six, J., Elliott, E. T. \& Paustian, K. Aggregate and soil organic matter dynamics under conventional and no-tillage systems. Soil Sci. Soc. Am. J. 63, 1350-1358, https://doi.org/10.2136/sssaj1999.6351350x (1999).

3. Wang, Z., Liu, L., Chen, Q., Wen, X. \& Liao, Y. Conservation tillage increases soil bacterial diversity in the dryland of northern China. Agron. Sustainable Dev. 36, 28, https://doi.org/10.1007/s13593-016-0366-x (2016).

4. Ayuke, F. O., Kihara, J., Ayaga, G. \& Micheni, A. N. Conservation agriculture enhances soil fauna richness and abundance in low input systems: examples from Kenya. Front. Environ. Sci. 7, 97, https://doi.org/10.3389/fenvs.2019.00097 (2019).

5. Castellanos-Navarrete, A. et al. Earthworm activity and soil structural changes under conservation agriculture in central Mexico. Soil Tillage Res. 123, 61-70, https://doi.org/10.1016/j.still.2012.03.011 (2012).

6. Palm, C., Blanco-Canqui, H., DeClerck, F., Gatere, L. \& Grace, P. Conservation agriculture and ecosystem services: An overview. Agric. Ecosyst. Environ. 187, 87-105, https://doi.org/10.1016/j.agee.2013.10.010 (2014).

7. Thorup-Kristensen, K. Are differences in root growth of nitrogen catch crops important for their ability to reduce soil nitrate-N content, and how can this be measured? Plant Soil 230, 185-195, https://doi.org/10.1023/A:1010306425468 (2001).

8. Snapp, S. S. et al. Evaluating cover crops for benefits, costs and performance within cropping system niches. Agron. J. 97, 322-332, https://doi.org/10.2134/agronj2005.0322 (2005).

9. Björkman, T. \& Shail, J. W. Using a buckwheat cover crop for maximum weed suppression after early vegetables. HortTechnology 23, 575-580, https://doi.org/10.21273/horttech.23.5.575 (2013).

10. Karasawa, T. \& Takahashi, S. Introduction of various cover crop species to improve soil biological P parameters and $\mathrm{P}$ uptake of the following crops. Nutri. Cycl. Agroecosyst. 103, 15-28, https://doi.org/10.1007/s10705-015-9715-4 (2015).

11. Smith, S. E. \& Read, D. J. Arbuscular mycorrhizaes. In Smith, S. E., Read, D. J. (eds.), Mycorrhizal symbiosis 3rd Edition. Academic Press, London, pp.13-187 (2008).

12. Mensah, J. A. et al. High functional diversity within species of arbuscular mycorrhizal fungi is associated with differences in phosphate and nitrogen uptake and fungal phosphate metabolism. Mycorrhiza 25, 533-546, https://doi.org/10.1007/s00572-0150631-x (2015).

13. Sawers, R. J. H. et al. Phosphorus acquisition efficiency in arbuscular mycorrhizal maize is correlated with the abundance of rootexternal hyphae and the accumulation of transcripts encoding PHT1 phosphate transporters. New Phytol. 214, 632-643, https://doi. org/10.1111/nph.14403 (2017).

14. Rillig, M. C. Arbuscular mycorrhizae and terrestrial ecosystem processes. Ecol Lett. 7, 740-754, https://doi.org/10.1111/j.14610248.2004.00620.x (2004).

15. Xie, H. et al. Long-term manure amendments reduced soil aggregate stability via redistribution of the glomalin-related soil protein in macroaggregates. Sci. Rep. 5, 14687, https://doi.org/10.1038/srep14687 (2015).

16. Miller, R. M. \& Jastrow, J. D. The role of mycorrhizal fungi in soil conservation 1. Mycorrhizae in sustainable agriculture, (mycorrhizaeinsu), 29-44 (1992).

17. Rillig, M. C. Arbuscular mycorrhizae, glomalin, and soil aggregation. Can. J. Soil Sci. 84, 355-363, https://doi.org/10.4141/S04-003 (2004).

18. Brito, I., Goss, M. J. \& Carvalho, M. D. Effect of tillage and crop on arbuscular mycorrhiza colonization of winter wheat and triticale under Mediterranean conditions. Soil Use Manage. 28, 202-208, https://doi.org/10.1111/j.1475-2743.2012.00404.x (2012).

19. Higo, M. et al. Diversity and vertical distribution of indigenous arbuscular mycorrhizal fungi under two soybean rotational systems. Biol. Fertil. Soils 49, 1085-1096, https://doi.org/10.1007/s00374-013-0807-5 (2013).

20. Kabir, Z. Tillage or no-tillage: impact on mycorrhizae. Can. J. Plant Sci. 85, 23-29, https://doi.org/10.4141/P03-160 (2005).

21. Rosner, K., Bodner, G., Hage-Ahmed, K. \& Steinkellner, S. Long-term soil tillage and cover cropping affected arbuscular mycorrhizal fungi, nutrient concentrations, and yield in sunflower. Agron. J. 110, 2664-2672, https://doi.org/10.2134/agronj2018.03.0177 (2018).

22. Thompson, J. P. Decline of vesicular-arbuscular mycorrhizae in long fallow disorder of field crops and its expression in phosphorus deficiency of sunflower. Aust. J. Agric. Res. 38, 847-867 (1987).

23. Higo, M. et al. Temporal variation of the molecular diversity of arbuscular mycorrhizal communities in three different winter cover crop rotational systems. Biol. Fertil. Soils 51, 21-32, https://doi.org/10.1007/s00374-014-0945-4 (2015). 
24. Dai, J. et al. No tillage enhances arbuscular mycorrhizal fungal population, glomalin-related soil protein content, and organic carbon accumulation in soil macroaggregates. J. Soils Sediments 15, 1055-1062, https://doi.org/10.1007/s11368-015-1091-9 (2015).

25. Karasawa, T., Kasahara, Y. \& Takebe, M. Differences in growth responses of maize to preceding cropping caused by fluctuation in the population of indigenous arbuscular mycorrhizal fungi. Soil Biol. Biochem. 34, 851-857, https://doi.org/10.1016/S00380717(02)00017-2 (2002).

26. Higo, M. et al. Can phosphorus application and cover cropping alter arbuscular mycorrhizal fungal communities and soybean performance after a five-year phosphorus-unfertilized crop rotational system? PeerJ 6, e4606 (2018).

27. Higo, M., Tatewaki, Y., Gunji, K., Kaseda, A. \& Isobe, K. Cover cropping can be a stronger determinant than host crop identity for arbuscular mycorrhizal fungal communities colonizing maize and soybean. PeerJ 7, e6403, https://doi.org/10.7717/peerj.6403 (2019).

28. Usuki, K., Yamamoto, H. \& Tazawa, J. Effects of previous cropping and tillage system on growth of maize and symbiotic association with arbusculer mycorrhizal fungi in central region of Japan. Jpn. J. Crop Sci. 76, 394-400, https://doi.org/10.1626/jcs.76.394 (2007).

29. Verbruggen, E., van der Heijden, M. G. A., Rillig, M. C. \& Kiers, E. T. Mycorrhizal fungal establishment in agricultural soils: factors determining inoculation success. New Phytol. 197, 1104-1109, https://doi.org/10.1111/j.1469-8137.2012.04348.x (2013).

30. Hart, M. M. \& Forsythe, J. A. Using arbuscular mycorrhizal fungi to improve the nutrient quality of crops; nutritional benefits in addition to phosphorus. Sci. Hortic. 148, 206-214, https://doi.org/10.1016/j.scienta.2012.09.018 (2012).

31. Jansa, J., Smith, F. A. \& Smith, S. E. Are there benefits of simultaneous root colonization by different arbuscular mycorrhizal fungi? New Phytol. 177, 779-789, https://doi.org/10.1111/j.1469-8137.2007.02294.x (2008).

32. Gosling, P., Jones, J. \& Bending, G. D. Evidence for functional redundancy in arbuscular mycorrhizal fungi and implications for agroecosystem management. Mycorrhiza 26, 77-83, https://doi.org/10.1007/s00572-015-0651-6 (2016).

33. Crossay, T. et al. Is a mixture of arbuscular mycorrhizal fungi better for plant growth than single-species inoculants? Mycorrhiza 29, 325-339, https://doi.org/10.1007/s00572-019-00898-y (2019).

34. Cofré, M. N. et al. Effects of cropping systems under no-till agriculture on arbuscular mycorrhizal fungi in Argentinean Pampas. Soil Use Manage. 33, 364-378, https://doi.org/10.1111/sum.12349 (2017).

35. Lu, X. \& Liao, Y. Effect of tillage treatment on the diversity of soil arbuscular mycorrhizal fungal and soil aggregate-associated carbon content. Front. Microbiol. 9, 2986, https://doi.org/10.3389/fmicb.2018.02986 (2018).

36. Berruti, A., Bianciotto, V. \& Lumini, E. Seasonal variation in winter wheat field soil arbuscular mycorrhizal fungus communities after non-mycorrhizal crop cultivation. Mycorrhiza 28, 535-548, https://doi.org/10.1007/s00572-018-0845-9 (2018).

37. Oehl, F. \& Koch, B. Diversity of arbuscular mycorrhizal fungi in no-till and conventionally tilled vineyards. J. Appl. Bot. Food Qual. 91, 56-60, https://doi.org/10.5073/JABFQ.2018.091.008 (2018).

38. Morimoto, S., Uchida, T., Matsunami, H. \& Kobayashi, H. Effect of winter wheat cover cropping with no-till cultivation on the community structure of arbuscular mycorrhizal fungi colonizing the subsequent soybean. Soil Sci. Plant Nutr. 64, 545-553, https:// doi.org/10.1080/00380768.2018.1486171 (2018).

39. Turrini, A. et al. Changes in the composition of native root arbuscular mycorrhizal fungal communities during a short-term cover crop-maize succession. Biol. Fertil. Soils 52, 643-653, https://doi.org/10.1007/s00374-016-1106-8 (2016).

40. Turrini, A. et al. Local diversity of native arbuscular mycorrhizal symbionts differentially affects growth and nutrition of three crop plant species. Biol. Fertil. Soils 54, 203-217, https://doi.org/10.1007/s00374-017-1254-5 (2018).

41. Vasar, M. et al. Increased sequencing depth does not increase captured diversity of arbuscular mycorrhizal fungi. Mycorrhiza 27, 761-773, https://doi.org/10.1007/s00572-017-0791-y (2017).

42. Hontoria, C., García-González, I., Quemada, M., Roldán, A. \& Alguacil, M. M. The cover crop determines the AMF community composition in soil and in roots of maize after a ten-year continuous crop rotation. Sci. Total Environ. 660, 913-922, https://doi. org/10.1016/j.scitotenv.2019.01.095 (2019).

43. Kokkoris, V., Li, Y., Hamel, C., Hanson, K. \& Hart, M. Site specificity in establishment of a commercial arbuscular mycorrhizal fungal inoculant. Sci. Total Environ. 660, 1135-1143, https://doi.org/10.1016/j.scitotenv.2019.01.100 (2019).

44. Parvin, S., Van Geel, M., Yeasmin, T., Lievens, B. \& Honnay, O. Variation in arbuscular mycorrhizal fungal communities associated with lowland rice (Oryza sativa) along a gradient of soil salinity and arsenic contamination in Bangladesh. Sci. Total Environ. 686, 546-554, https://doi.org/10.1016/j.scitotenv.2019.05.450 (2019).

45. Xiao, D. et al. Effects of different legume species and densities on arbuscular mycorrhizal fungal communities in a karst grassland ecosystem. Sci. Total Environ. 678, 551-558, https://doi.org/10.1016/j.scitotenv.2019.04.293 (2019).

46. Kobae, Y. \& Ohtomo, R. An improved method for bright-field imaging of arbuscular mycorrhizal fungi in plant roots. Soil Sci. Plant Nutr. 62, 27-30, https://doi.org/10.1080/00380768.2015.1106923 (2016).

47. Giovannetti, M. \& Mosse, B. An evaluation of techniques for measuring vesicular arbuscular mycorrhizal infection in roots. New Phytol. 84, 489-500, https://doi.org/10.1111/j.1469-8137.1980.tb04556.x (1980).

48. Bray, R. H. \& Kurtz, L. T. Determination of total, organic, and available forms of phosphorus in soils. Soil Sci. 59, 39-45 (1945).

49. Ishii, T. \& Hayano, K. A method for the estimation of phosphodiesterse activity in soil. Jpn. J. Soil Sci. Plant Nutr. 45, 505-508 (In Japanese) (1974).

50. Hayano, K. A method for the determination of $\beta$-glucosidase activity in soil. Soil Sci. Plant Nutr. 19, 103-108, https://doi.org/ 10.1080/00380768.1973.10432524(1973).

51. Helgason, T., Daniell, T. J., Husband, R., Fitter, A. H. \& Young, J. P. W. Ploughing up the wood-wide web? Nature 394, 431-431, https://doi.org/10.1038/28764 (1998).

52. Simon, L., Lalonde, M. \& Bruns, T. D. Specific amplification of 18 S fungal ribosomal genes from vesicular-arbuscular endomycorrhizal fungi colonizing roots. Appl. Environ. Microbiol. 58, 291-295 (1992).

53. Sato, K., Suyama, Y., Saito, M. \& Sugawara, K. A new primer for discrimination of arbuscular mycorrhizal fungi with polymerase chain reaction-denature gradient gel electrophoresis. Grassl. Sci. 51, 179-181, https://doi.org/10.1111/j.1744-697X.2005.00023.x (2005).

54. Higo, M., Kang, D. J. \& Isobe, K. First report of community dynamics of arbuscular mycorrhizal fungi in radiocesium degradation lands after the Fukushima-Daiichi Nuclear disaster in Japan. Sci. Rep. 9, 8240, https://doi.org/10.1038/s41598-019-44665-7 (2019).

55. Caporaso, J. G. et al. QIIME allows analysis of high-throughput community sequencing data. Nat. Methods 7, 335-336, https://doi. org/10.1038/nmeth.f.303 (2010).

56. Kumar, S., Stecher, G. \& Tamura, K. MEGA7: molecular evolutionary genetics analysis version 7.0 for bigger datasets. Mol. Biol. Evol. 33, 1870-1874, https://doi.org/10.1093/molbev/msw054 (2016).

57. Lenth, R. Emmean: estimated marginal means, aka least-squares means. R package version 1.3.4, https://cran.r-project.org/ package $=$ emmeans $(2019)$

58. Chao, A. et al. Rarefaction and extrapolation with Hill numbers: a framework for sampling and estimation in species diversity studies. Ecol. Monogr. 84, 45-67, https://doi.org/10.1890/13-0133.1 (2014).

59. Oksanen, J. et al Vegan: Community Ecology Package. R package version 2.5-4, https://cran.r-project.org/web/packages/vegan/ index.html (2019).

60. Cáceres, M. \& Legendre, P. Associations between species and groups of sites: indices and statistical inference. Ecology 90, 3566-3574, https://doi.org/10.1890/08-1823.1 (2009).

61. Chazdon, R. L. et al. A novel statistical method for classifying habitat generalists and specialists. Ecology 92, 1332-1343, https://doi. org/10.1890/10-1345.1 (2011). 
62. Oehl, F. et al. Impact of land use intensity on the species diversity of arbuscular mycorrhizal fungi in agroecosystems of Central Europe. Appl. Environ. Microbiol. 69, 2816-2824, https://doi.org/10.1128/AEM.69.5.2816-2824.2003 (2003).

63. Giovannetti, M., Azzolini, D. \& Citernesi, A. S. Anastomosis formation and nuclear and protoplasmic exchange in arbuscular mycorrhizal fungi. Appl. Environ. Microbiol. 65, 5571-5575 (1999).

64. Daniell, T. J., Husband, R., Fitter, A. H. \& Young, J. P. W. Molecular diversity of arbuscular mycorrhizal fungi colonising arable crops. FEMS Microbiol. Ecol. 36, 203-209, https://doi.org/10.1016/S0168-6496(01)00134-9 (2001).

65. Biermann, B. \& Linderman, R. G. Use of vesicular-arbuscular mycorrhizal roots, intraradical vesicles and extraradical vesicles as inoculum. New Phytol. 95, 97-105, https://doi.org/10.1111/j.1469-8137.1983.tb03472.x (2006).

66. Schalamuk, S. \& Cabello, M. Arbuscular mycorrhizal fungal propagules from tillage and no-tillage systems: possible effects on Glomeromycota diversity. Mycologia 102, 261-268, https://doi.org/10.3852/08-118 (2010).

67. Dumbrell, A. J., Nelson, M., Helgason, T., Dytham, C. \& Fitter, A. H. Relative roles of niche and neutral processes in structuring a soil microbial community. ISME J. 4, 337-345, https://doi.org/10.1038/ismej.2009.122 (2010).

68. Kohout, P. et al. Comparison of commonly used primer sets for evaluating arbuscular mycorrhizal fungal communities: Is there a universal solution? Soil Biol. Biochem. 68, 482-493, https://doi.org/10.1016/j.soilbio.2013.08.027 (2014).

69. Gottshall, C. B., Cooper, M. \& Emery, S. M. Activity, diversity and function of arbuscular mycorrhizae vary with changes in agricultural management intensity. Agric. Ecosyst. Environ. 241, 142-149, https://doi.org/10.1016/j.agee.2017.03.011 (2017).

70. Séry, D. J.-M., van Tuinen, D., Drain, A., Mounier, A. \& Zézé, A. The genus Rhizophagus dominates arbuscular mycorrhizal fungi communities in contrasted cassava field soils in Côte d'Ivoire. Rhizosphere 7, 8-17, https://doi.org/10.1016/j.rhisph.2018.06.007 (2018).

71. Higo, M., Takahashi, Y., Gunji, K. \& Isobe, K. How are arbuscular mycorrhizal associations related to maize growth performance during short-term cover crop rotation? J. Sci. Food Agric. 98, 1388-1396, https://doi.org/10.1002/jsfa.8606 (2018).

72. Higo, M. et al. Impact of a 5-year winter cover crop rotational system on the molecular diversity of arbuscular mycorrhizal fungi colonizing roots of subsequent soybean. Biol. Fertil. Soils 50, 913-926, https://doi.org/10.1007/s00374-014-0912-0 (2014).

73. Avio, L. et al. Impact of nitrogen fertilization and soil tillage on arbuscular mycorrhizal fungal communities in a Mediterranean agroecosystem. Soil Biol. Biochem. 67, 285-294, https://doi.org/10.1016/j.soilbio.2013.09.005 (2013).

74. de Pontes, J. S. et al. Diversity of arbuscular mycorrhizal fungi in the Brazilian's Cerrado and in soybean under conservation and conventional tillage. Appl. Soil Ecol. 117-118, 178-189, https://doi.org/10.1016/j.apsoil.2017.04.023 (2017).

75. Hallama, M., Pekrun, C., Lambers, H. \& Kandeler, E. Hidden miners-the roles of cover crops and soil microorganisms in phosphorus cycling through agroecosystems. Plant Soil 434, 7-45, https://doi.org/10.1007/s11104-018-3810-7 (2019).

76. Ye, X. et al. The influence of a year-round tillage and residue management model on soil $\mathrm{N}$ fractions in a wheat-maize cropping system in central China. Sci. Rep. 9, 4767, https://doi.org/10.1038/s41598-019-41409-5 (2019).

77. Liebman, M. \& Sundberg, D. N. Seed mass affects the susceptibility of weed and crop species to phytotoxins extracted from red clover shoots. Weed Sci. 54, 340-345, https://doi.org/10.1614/WS-05-54.2.340a (2006).

78. Schoenau, J. J. \& Campbell, C. A. Impact of crop residues on nutrient availability in conservation tillage systems. Can. J. Plant Sci. 76, 621-626, https://doi.org/10.4141/cjps96-111 (1996).

79. Brennan, J. et al. The effect of tillage system and residue management on grain yield and nitrogen use efficiency in winter wheat in a cool Atlantic climate. Eur. J. Agron. 54, 61-69, https://doi.org/10.1016/j.eja.2013.11.009 (2014).

80. Navarro-Noya, Y. E. et al. Relative impacts of tillage, residue management and crop-rotation on soil bacterial communities in a semiarid agroecosystem. Soil Biol. Biochem. 65, 86-95, https://doi.org/10.1016/j.soilbio.2013.05.009 (2013).

81. Shen, Y., McLaughlin, N., Zhang, X., Xu, M. \& Liang, A. Effect of tillage and crop residue on soil temperature following planting for a Black soil in Northeast China. Sci. Rep. 8, 4500, https://doi.org/10.1038/s41598-018-22822-8 (2018).

82. Li, R. et al. Effects on soil temperature, moisture, and maize yield of cultivation with ridge and furrow mulching in the rainfed area of the Loess Plateau, China. Agric. Water Manage. 116, 101-109, https://doi.org/10.1016/j.agwat.2012.10.001 (2013).

83. Hawkes, C. V., Hartley, I. P., Ineson, P. \& Fitter, A. H. Soil temperature affects carbon allocation within arbuscular mycorrhizal networks and carbon transport from plant to fungus. Glob. Chang. Biol. 14, 1181-1190, https://doi. org/10.1111/j.1365-2486.2007.01535.x (2008).

84. Heinemeyer, A. et al. Impact of soil warming and shading on colonization and community structure of arbuscular mycorrhizal fungi in roots of a native grassland community. Glob. Chang. Biol. 10, 52-64, https://doi.org/10.1111/j.1365-2486.2003.00713.x (2004).

85. Higo, M., Isobe, K., Matsuda, Y., Ichida, M. \& Torigoe, Y. Influence of sowing season and host crop identity on the community structure of arbuscular mycorrhizal fungi colonizing roots of two different gramineous and leguminous crop species. Adv. Microbiol. 5, 107-116, https://doi.org/10.4236/aim.2015.52011 (2015).

\section{Acknowledgements}

This study was financially supported by a Grant-in-Aid for Scientific Research (C) Grant Numbers JP19K06005.

\section{Author contributions}

M.H. planned and designed the research; Masao Higo, Yuya Tatewaki, Karen Iida and Kana Yokota performed the research and participated in the sampling; Katsunori Isobe provided critical feedback to improve the design and selection of the methodology of the experiment; M.H. analyzed the data and wrote the manuscript.

\section{Competing interests}

The authors declare no competing interests.

\section{Additional information}

Supplementary information is available for this paper at https://doi.org/10.1038/s41598-020-58942-3.

Correspondence and requests for materials should be addressed to M.H.

Reprints and permissions information is available at www.nature.com/reprints.

Publisher's note Springer Nature remains neutral with regard to jurisdictional claims in published maps and institutional affiliations. 
(c) (i) Open Access This article is licensed under a Creative Commons Attribution 4.0 International License, which permits use, sharing, adaptation, distribution and reproduction in any medium or format, as long as you give appropriate credit to the original author(s) and the source, provide a link to the Creative Commons license, and indicate if changes were made. The images or other third party material in this article are included in the article's Creative Commons license, unless indicated otherwise in a credit line to the material. If material is not included in the article's Creative Commons license and your intended use is not permitted by statutory regulation or exceeds the permitted use, you will need to obtain permission directly from the copyright holder. To view a copy of this license, visit http://creativecommons.org/licenses/by/4.0/.

(C) The Author(s) 2020 